\title{
Estimation of Minimum Miscibility Pressure for Hydrocarbon Gas Injection Based on EOS
}

\author{
Liqaa I. Hadi and Sameera M. Hamd-Allah ${ }^{2 *}$ \\ 'Department of Petroleum Engineering,University of Baghdad, Baghdad, Iraq,liqaadr@gmail.com \\ 2Department of Petroleum Engineering, University of Baghdad, Baghdad, Iraq,sameerahmdulla@yahoo.com \\ * Coressponding author: Dr. Sameera M.Hamd-Allah, sameerahmdulla@yahoo.com
}

Published online: 30 September 2020

Abstract- The important parameter used for determining the probable application of miscible displacement is the MMP (minimum miscibility pressure). In enhanced oil recovery, the injection of hydrocarbon gases can be a highly efficient method to improve the productivity of the well especially if miscibility developed through the displacement process. There are a lot of experiments for measuring the value of the miscibility pressure, but they are expensive and take a lot of time, so it's better to use the mathematical equations because of it inexpensive and fast. This study focused on calculating MMP required to inject hydrocarbon gases into two reservoirs namely Sadi and Tanomaa/ East Baghdad field. Modified Peng Robenson Equation of State was used to estimate MMP values for the two samples. The parameters of this equation have been tuned by splitting the plus component and regression process to obtain the best match for PVT properties between the calculated and that measured in the laboratory. Then the MMPs value compared with the results most reliable correlation. Ternary diagram for these samples has been constructed to illustrate the occurrence of miscibility.

Keywords-Minimum miscibility pressure, hydrocarbon gas injection, Miscible displacement.

\section{Introduction}

Minimum miscibility pressure is the lowest pressure for which the injection gas can develop miscibility with reservoir oil at reservoir temperature[11]. In the technique of enhanced oil recovery, several injection gases are used including $\mathrm{CO}_{2}$, hydrocarbon gas, acid gases, and $\mathrm{N}_{2}[14]$. In the processes of hydrocarbon gas injection, the process is achieved to miscible displacements when gas injected into the reservoir at a suitable pressure condition. several methods are used in order to measure the MMP such as slim tube test, vapourliquid equilibrium, rising bubble test, slim tube composition simulator, thermodynamic models, EOS and empirical correlations[1]. Equation of state (EOS) is considered an analytical expression describing the relation of pressure $(\mathrm{P})$ to the volume $\&$ the temperature (T). The simulation of the phase behaviour of a reservoir fluid system is performed using an Equation of State (EOS). An EOS does not attempt to model detailed physics but they are semiempirical equations which are using a limited number of empirical parameters[17]. In the petroleum industry, the most commonly used EOS in PVT simulation is the Peng-Robinson (PR) and the
Soave-Redlick-Kwong(SRK) [2,3]. Both of these are cubic EOS. Equations of State are popular in the last years because of their simplicity and relative accuracy[15]. There are many researchers who used the equations of state to calculate the minimum miscibility pressure such as.

Benmekkl and Mansoorl, (1988) [4] used Peng Robenson equation of state with van der Waals Mixing Rules to evaluate phase behaviour and predicted MMP of reservoir fluids of vaporizing gas drive (VGD). The results were compared with experimental data indicates that the equation of state overestimates the (MMP), but when the PR-EOS joined with (correct version of van der Waals mixing rules) the MMP prediction became more accurately.

Ahmed,( 2007) [15] developed a practical and generalized methodology for calculating MMP of crude oil by hydrocarbon gases and $\mathrm{CO}_{2}$ injection. This method was based on applying modified Peng and Robinson EOS with newly introduced (Miscibility function), miscibility function was designed to predicate an accurate value of MMP. The proposed approach shows a good agreement when it applied to reproduce the experimentally reported 
MMP data of Metcalfe and Glaso. It was capable of predicate MMP for $\mathrm{CO} 2$ and hydrocarbon gases with AERR of $3.4 \%$.

\section{Reservoir Fluid Properties.}

The properties of the reservoir fluids in EB field are presented in table 1 . The original composition of these two samples are given in appendix A, table A1 and A2 .

Table 1: selected reservoir fluid properties.

\begin{tabular}{|c|c|c|c|c|c|}
\hline $\begin{array}{c}\text { Samples from } \\
\text { well/ } \\
\text { reservoir }\end{array}$ & $\begin{array}{c}\text { Initial } \\
\text { pressure } \\
\text { Bar }\end{array}$ & $\begin{array}{c}\text { Temp. } \\
{ }^{0} \mathrm{~F}\end{array}$ & API & $\begin{array}{c}\text { GOR } \\
\mathrm{m}^{3} / \mathrm{m}^{3}\end{array}$ & $\begin{array}{c}\text { Depth } \\
\mathrm{m}\end{array}$ \\
\hline $\begin{array}{c}\text { Well EB1- } \\
\text { Sadi }\end{array}$ & 265.3 & 179.6 & 25.5 & 71.51 & 2321 \\
\hline $\begin{array}{c}\text { Well EB11- } \\
\text { Tanomaa }\end{array}$ & 227.89 & 164 & 19 & 78.08 & 2055 \\
\hline
\end{tabular}

\section{Splitting and Grouping.}

The way for presenting the data to us in a laboratory report commonly not suitable for using in EOS model, therefore, two additional steps should be performed (splitting and grouping). In this study, we used Eclipse/ PVTi software for characterization of oil samples. The insufficient description of heavy hydrocarbon components minimises the accuracy of the PVT predictions[12]. For this reason, PVT matching procedure usually starts with splitting any plus components into many pseudo components and then grouping components that have a similar molecular weight in the same group. The composition of these two samples is shown in tables 2 and 3 after splitting and grouping process as suggested by Whitson[13]. where the properties of $\mathrm{C}_{24+}$ are calculated based on Riazi and Daubert's correlation[10].

\section{Regression Tuning of EOS.}

After splitting the plus component mole fraction, the last stage is adjusting the parameters of the selected equation of state. Many trials have done based on the approach of Gani and Fredenslund(1987) [5] that based on establishing the sensitively of the predicted results in order to achieve a perfect matching between the observed PVT data and that calculated from EOS. The main regression parameters that allowed to get the best match if it changed are (critical pressure $(\mathrm{Pc})$, critical temperature(Tc), omega a $(\Omega \mathrm{a})$, omega $\mathrm{b}(\Omega \mathrm{b}))[15]$. Figure (1) and figure (2) show the match between observed and calculated physical properties for wells EB1 and EB11 after regression process. Table 4 shows the calculated and observed saturation pressure values and AERR (Absolute Relative Error) after the regression process for wells EB1 and EB11. Where AERR and AAERR(Avarage Absolute Relative Error) equations are
- AERR=((Xexp-Xest $) / X \exp ) * 100 \%$

- $A A E R R=\left(\frac{1}{n_{d}}\right) \sum_{i=1}^{n_{d}}|A E R R|$

where

Xest : estimated value

Xexp : experimental values.

Table 2 : composition of EB1-Sadi reservoir after splitting and grouping

\begin{tabular}{|c|c|}
\hline Components & $\mathrm{Zi}$ (percent) \\
\hline $\mathrm{N}_{2}$ & 0 \\
\hline $\mathrm{CO}_{2}$ & 0.42 \\
\hline $\mathrm{C}_{1}$ & 29.36 \\
\hline $\mathrm{C}_{2}$ & 8.25 \\
\hline $\mathrm{C}_{3}$ & 6.4 \\
\hline $\mathrm{IC}_{4}$ & 1.48 \\
\hline $\mathrm{NC}_{4}$ & 3.47 \\
\hline $\mathrm{IC}_{5}$ & 1.85 \\
\hline $\mathrm{NC}_{5}$ & 1.88 \\
\hline $\mathrm{C}_{6+}$ & 17.754 \\
\hline $\mathrm{C}_{13+}$ & 15.507 \\
\hline $\mathrm{C}_{24+}$ & 13.629 \\
\hline $\mathrm{sum}$ & $100 \%$ \\
\hline \multicolumn{2}{|c}{}
\end{tabular}

Table 3: composition of EB11- Tanomaa reservoir after splitting and grouping.

\begin{tabular}{|c|c|}
\hline Components & $\mathrm{Zi}$ (percent) \\
\hline $\mathrm{N}_{2}$ & 0.51 \\
\hline $\mathrm{CO}_{2}$ & 0.81 \\
\hline $\mathrm{C}_{1}$ & 37.61 \\
\hline $\mathrm{C}_{2}$ & 5.9 \\
\hline $\mathrm{C}_{3}$ & 5.92 \\
\hline $\mathrm{IC}_{4}$ & 1.92 \\
\hline $\mathrm{NC}_{4}$ & 3.05 \\
\hline $\mathrm{IC}_{5}$ & 1.52 \\
\hline $\mathrm{NC}_{5}$ & 1.92 \\
\hline $\mathrm{C}_{6+}$ & 10.285 \\
\hline $\mathrm{C}_{13+}$ & 11.324 \\
\hline $\mathrm{C}_{24+}$ & 19.231 \\
\hline $\mathrm{sum}$ & $100 \%$ \\
\hline
\end{tabular}

Table 4: calculated and observed saturation pressure for EB1 and EB11.

\begin{tabular}{|c|c|c|c|}
\hline Wells/reservoir & $\begin{array}{c}\text { Observed } \\
\text { saturation } \\
\text { pressure } \\
(\text { Bar })\end{array}$ & $\begin{array}{c}\text { calculated } \\
\text { saturation } \\
\text { pressure } \\
\text { (Bar) }\end{array}$ & AERR\% \\
\hline EB1-Sadi & 130.8732 & 135.9887 & 3.9 \\
\hline EB11-Tanomaa & 157.3967 & 154.3356 & 1.944 \\
\hline
\end{tabular}




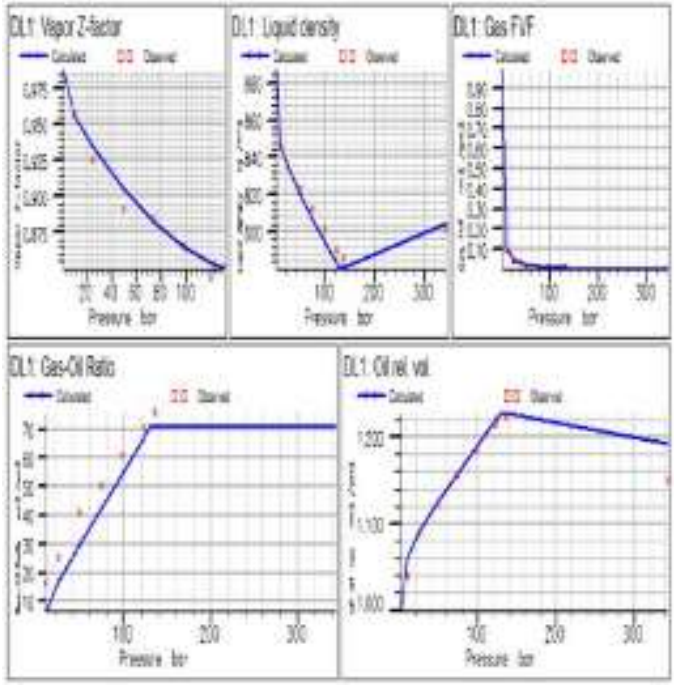

Figure 1: calculated and observed PVT properties for EB1-Sadi reservoir.

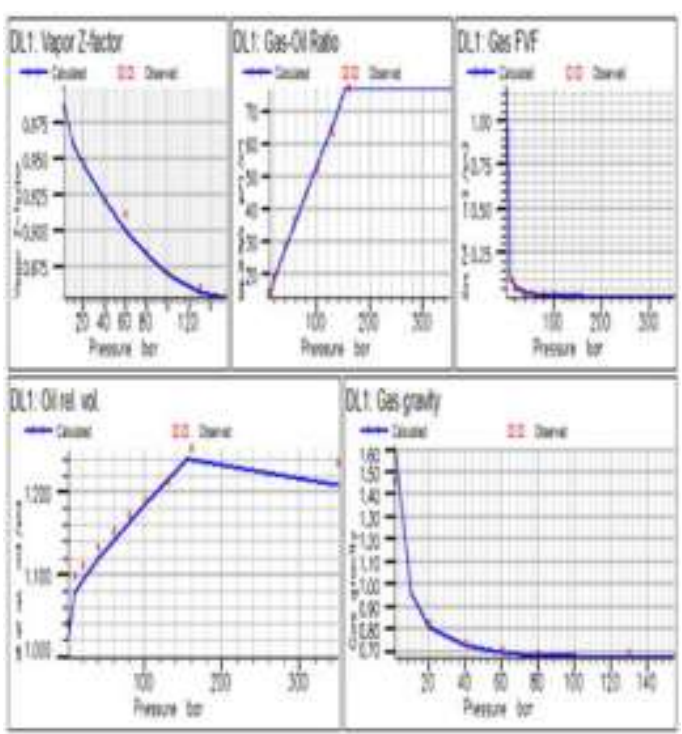

Figure2: calculated and observed PVT properties for EB11-Tanomaa reservoir

\section{Injection Gas Composition}

The injected gas design greatly contributes to the success of the miscible gas displacement process so, in order to achieve miscibility with the reservoir fluid at the lowest pressure, the composition of injected gas should be close to the composition of equilibrium gas with crude oil in the reservoir. For this reason, the produced gas is a good source for gas injection and it is more economical to reinject part or all of the produced gas into the reservoir[7]. Therefore the injected gases used in this study have a composition similar to that of the gas coming out of the separator. Table 5 and Table 6 represent the injection gas composition for wells EB1 and EB11 respectively.
Table 5: injection gas composition for well EB1-Sadi reservoir

\begin{tabular}{|c|c|}
\hline Components & $\mathrm{Zi}$ (percent) \\
\hline $\mathrm{N} 2$ & 0 \\
\hline $\mathrm{C} 1$ & 48.23 \\
\hline $\mathrm{CO} 2$ & 0.55 \\
\hline $\mathrm{C} 2$ & 14.12 \\
\hline $\mathrm{C} 3$ & 7.69 \\
\hline $\mathrm{IC} 4$ & 7.56 \\
\hline $\mathrm{NC} 4$ & 6.88 \\
\hline $\mathrm{IC} 5$ & 7.34 \\
\hline $\mathrm{NC} 5$ & 7.38 \\
\hline $\mathrm{C} 6+$ & 0.25 \\
\hline sum & $100 \%$ \\
\hline
\end{tabular}

Table 6: injection gas composition for well EB11Tanomaa reservoir

\begin{tabular}{|c|c|}
\hline Components & $\mathrm{Zi}$ (percent) \\
\hline $\mathrm{N} 2$ & 0 \\
\hline $\mathrm{C} 1$ & 43 \\
\hline $\mathrm{CO} 2$ & 21.99 \\
\hline $\mathrm{C} 2$ & 13.8 \\
\hline $\mathrm{C} 3$ & 6.17 \\
\hline $\mathrm{IC} 4$ & 2.88 \\
\hline $\mathrm{NC} 4$ & 5.71 \\
\hline IC5 & 5.93 \\
\hline NC5 & 0.52 \\
\hline C6+ & $100 \%$ \\
\hline sum & \\
\hline & \\
\hline & \\
\hline & \\
\hline & \\
\hline & \\
\hline & \\
\hline & \\
\hline
\end{tabular}




\section{MMP Estimation and Ternary Diagram.}

Finally, after a suitable matching obtained between the calculated and observed PVT properties, MMP can be calculated by PVTi software at reservoir temperature by using modified Peng and Robinson equation of state. The MMP values for wells EB1 and EB11 are shown in table (7). Ternary diagrams are plotted for the MCM process to illustrate the occurrence of miscibility. Figures 3 and 4 show the ternary diagram for wells EB1 and EB11 the red point represents the oil composition for EB1-Sadi sample $(\mathrm{C} 1+\mathrm{N} 2=29.36, \quad \mathrm{C} 2-6+\mathrm{CO} 2=23.75)$ and $\mathrm{EB} 11-$ Tanomaa sample $(\mathrm{C} 1+\mathrm{N} 2=38.12, \quad \mathrm{C} 2-6+\mathrm{CO} 2=21.04)$. The black point represents the injected gas composition for $\mathrm{EB} 1$-Sadi $(\mathrm{C} 1+\mathrm{N} 2=43, \mathrm{C} 2-\mathrm{C} 6+\mathrm{CO} 2=56.48)$, $\mathrm{EB} 11$ Tanomaa $(\mathrm{C} 1+\mathrm{N} 2=48.23, \mathrm{C} 2-\mathrm{C} 6+\mathrm{CO} 2=51.52)$.

Table 7 :MMPs values for wells EB1 and EB11

\begin{tabular}{|c|c|}
\hline Well/ reservoir & MMP (Bar) \\
\hline EB1-Sadi & 448.2 \\
\hline EB11-Tanomaa & 452.12 \\
\hline
\end{tabular}

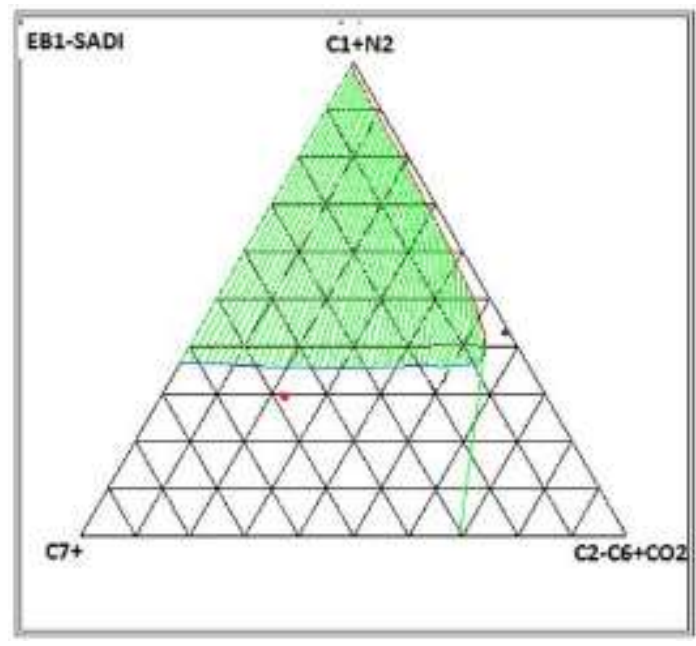

Figure 3: ternary diagram for EB1-Sadi reservoir.

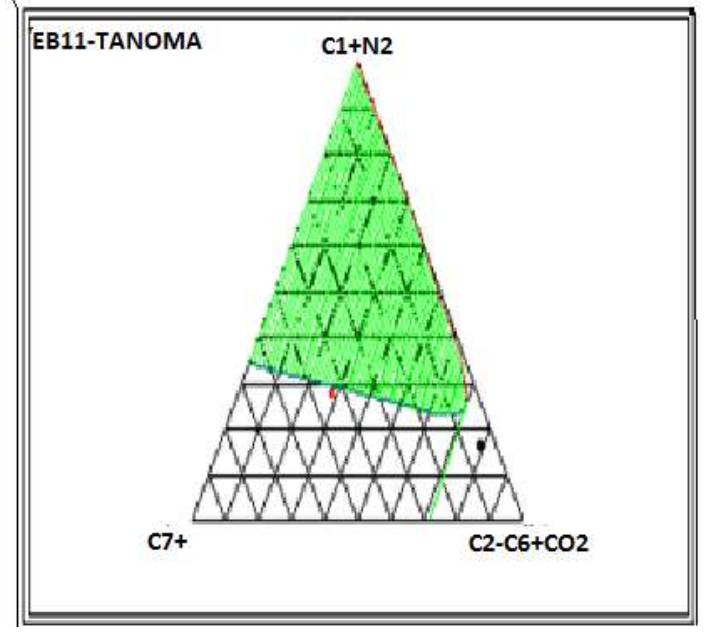

Figure 4: ternary diagram for EB11- Tanomaa

\section{Comparison with impreical correlation.}

Table (8) shows a comparison between the MMP calculated by PR EOS and calculated by the empirical correlations Firoozabadi (1986)[1] and Glaso (1985)[6] for the two fluid samples from well (EB1, EB11). The absolute relative error (AERR) calculated between MMP by EOS and by Firoozabadi correlation for EB1 is $0.704 \%$ and AERR for EB11 is $0.96 \%$, then the average absolute relative error(AAERR) for EB1 and EB11 with Firoozabadi correlation was calculated to be about 0.832 $\%$. AERR also calculated between EOS result and Glaso correlation for EB1 it is $1.822 \%$ and for EB11 it is $2.57 \%$ and the AAERR for EB1 and EB11 with Glaso correlation equal to $2.195 \%$. This less value of AAERR with the correlation that based on experimental results prove that the EOS can accurately calculate minimum miscibility pressure after adjustment by the regression process. Glaso and Firoozabadi correlations are shown below.

\section{A-Glaso correlation}

Equation (1)

$(\mathrm{Pm})_{\min x=34}=6329-25.41 \mathrm{Y}-(46.745-0.185 \mathrm{Y}) \mathrm{Z}+(1.127 * 10$

$\left.{ }^{12} \mathrm{Y}^{5.258} \exp \left(319.8 Z \mathrm{Y}^{-1.703}\right)\right) \mathrm{T}$

Equation (2)

$(\mathrm{Pm})_{\min x=44}=5503-19.238 \mathrm{Y}-(80.913-.273 \mathrm{Y}) \mathrm{Z}+\left(1.7 * 10^{-}\right.$

$\left.{ }^{9} \mathrm{Y}^{3.73} \exp \left(13.567 \mathrm{ZY} \mathrm{Y}^{-1.109}\right)\right) \mathrm{T}$

Equation (3)

$(\mathrm{Pm}) \min _{\mathrm{x}=54}=7437-25.703 \mathrm{Y}-(73.515-$

$0.214 \mathrm{Y}) \mathrm{Z}+\left(4.92 * 10^{-14} \mathrm{Y}^{5.52} \exp \left(21.706 \mathrm{zy}^{-1.109}\right)\right) \mathrm{T}$ 
where

$\mathrm{X}$ : intermediate component molecular weight in the injection gas.

$\mathrm{Y}: \mathrm{C}_{7+}$ molecular weight in the reservoir oil.

$\mathrm{Z}$ : methane per cent in the injection gas.

$\mathrm{T}$ : temperature, ${ }^{\circ} \mathrm{F}$.

\section{B-Firoozabadi correlation}

$\mathrm{MMP}=9433-188 * 10^{3} *\left(\frac{X_{i n t}}{M_{C 7+} T^{0.25}}\right)+1430 * 10^{3} *\left(\frac{X_{i n t}}{M_{C 7+} T^{0.25}}\right)^{2}$

where

MMP: minimum miscibility pressure.

$\mathrm{Mwc}_{7+}$ : molecular weight of heptane plus.

two-fluid: mole fraction of intermediate components

$\mathrm{T}$ : temperature, ${ }^{\circ} \mathrm{F}$.

Table 8 :comparison between EOS results and empreical correlation.

\begin{tabular}{|c|c|c|c|c|c|}
\hline $\begin{array}{c}\text { Well/ } \\
\text { reservoi } \\
\mathrm{r}\end{array}$ & $\begin{array}{c}\text { MMP } \\
\text { EOS } \\
\text { (Bar) }\end{array}$ & $\begin{array}{c}\text { MMP } \\
\text { Firoozaba } \\
\text { di (Bar) }\end{array}$ & $\begin{array}{c}\text { AER } \\
\text { R\% }\end{array}$ & $\begin{array}{c}\text { MMP } \\
\text { Glaso } \\
\text { (Bar) }\end{array}$ & $\begin{array}{c}\text { AER } \\
\text { R\% }\end{array}$ \\
\hline $\begin{array}{c}\text { EB1- } \\
\text { Sadi }\end{array}$ & 438.95 & 442.06 & 0.70 & 447.1 & $\begin{array}{c}1.82 \\
2\end{array}$ \\
\hline $\begin{array}{c}\text { EB11- } \\
\text { Tanoma } \\
\text { a }\end{array}$ & 457.64 & 462.12 & 0.96 & 469.71 & 2.57 \\
\hline $\begin{array}{c}\text { AAERR } \\
\%\end{array}$ & & & 0.83 & & $\begin{array}{c}2.19 \\
5\end{array}$ \\
\hline
\end{tabular}

\section{Conclusions.}

1- Comparison of EOS results with the most important existing empirical correlations shows that there was a good agreement with correlation results.

2- The match between calculated and measurement values was obtained by adjusting $(\mathrm{Pc}, \mathrm{Tc}$,) that have an effect on the PR-EOS calculation.

3- The MMP values decrease with increasing $\left(\mathrm{C}_{2}-\mathrm{C}_{5}\right)$ molecular weight in the injection gas.

\section{Appendix A}

Table A1: composition of EB1- Sadi reservoir

\begin{tabular}{|c|c|}
\hline Components & $\begin{array}{c}\mathrm{Zi} \\
\text { (percent) }\end{array}$ \\
\hline $\mathrm{N}_{2}$ & 0 \\
\hline $\mathrm{CO}_{2}$ & 0.42 \\
\hline $\mathrm{C}_{1}$ & 29.36 \\
\hline $\mathrm{C}_{2}$ & 8.25 \\
\hline $\mathrm{C}_{3}$ & 6.4 \\
\hline $\mathrm{IC}_{4}$ & 1.48 \\
\hline $\mathrm{NC}_{4}$ & 3.47 \\
\hline $\mathrm{IC}_{5}$ & 1.85 \\
\hline $\mathrm{NC}_{5}$ & 1.88 \\
\hline $\mathrm{C}_{6+}$ & 46.89 \\
\hline $\mathrm{sum}$ & $100 \%$ \\
\hline
\end{tabular}

$$
\mathrm{MW}_{\mathrm{C} 6+}=340
$$

Table A2: composition of EB11-

Tanomaa reservoir

\begin{tabular}{|c|c|}
\hline Components & $\begin{array}{c}\mathrm{Zi} \\
\text { (percent) }\end{array}$ \\
\hline $\mathrm{N}_{2}$ & 0.51 \\
\hline $\mathrm{C}_{1}$ & 37.61 \\
\hline $\mathrm{CO}_{2}$ & 0.81 \\
\hline $\mathrm{C}_{2}$ & 5.9 \\
\hline $\mathrm{C}_{3}$ & 5.92 \\
\hline $\mathrm{IC}_{4}$ & 1.92 \\
\hline $\mathrm{NC}_{4}$ & 3.05 \\
\hline $\mathrm{IC}_{5}$ & 1.52 \\
\hline $\mathrm{NC}_{5}$ & 1.92 \\
\hline $\mathrm{C}_{6+}$ & 40.84 \\
\hline $\mathrm{sum}$ & $100 \%$ \\
\hline
\end{tabular}

$$
\mathrm{MW}_{\mathrm{C} 6+}=344
$$

\section{References}

[1] A. Firoozabadi and K. Aziz, "Analysis and Correlation of Nitrogen and Lean-Gas Miscibility Pressure.," SPE Reserv. Eng. (Society Pet. Eng., vol. 1, no. 6, pp. 575-582, 1986.

[2] B. S. Jhaveri and G. K. Youngren, "Threeparameter modification of the Peng-Robinson equation of state to improve volumetric predictions," SPE Reserv. Eng. (Society Pet. Eng., vol. 3, no. 3, pp. 1033-1040, 1988.

[3] D. Peng and D. B. Robinson, "A New TwoConstant Equation of State," vol. 15, no. 1, pp. 59-64, 1976. 
[4] E. H. Benmekki and G. A. Mansoori, "Minimum Miscibility Pressure Prediction With Equations of State.," SPE Reserv. Eng. (Society Pet. Eng., vol. 3, no. 2, pp. 559-564, 1988.

[5] Gani, R., and Fredenslund, A., "Thermodynamics of Pe troleum Mixtures Containing Heavy Hydrocarbons Am Expert Tuning System" Industrial and Engineering Chemistry Research.

[6] Glaso, "Generalized Minimum Miscibility Pressure Correlation," Spe, vol. 12, no. December, pp. 927-34, 1985.

[7] I. Farzad and M. Amani, "Evaluating Reservoir Production Strategies in Miscible and Immiscible Gas-Injection Projects," 2007.

[8] J. A. Shaikh, C. Fz-llc, P. Sah, C. Asia, and P. Sdn, "SPE 144023 Experimental PVT Data Needed to Develop EOS Model for EOR Projects," no. July, pp. 19-21, 2011.

[9] M. Kanatbayev, K. K. Meisingset, K. Uleberg, and S. Asa, "Comparison of MMP Estimation Methods with Proposed Workflow," no. April,pp. 1-11, 2015.

[10]M. R. Riazi, “A Continuous Model for C $7+$
Fraction Characterization of Petroleum," pp. 4299-4307, 1997.

[11] O. Adekunle and B. T. Hoffman, "Minimum miscibility pressure studies in the Bakken," SPE - DOE Improv. Oil Recover. Symp. Proc., vol. 2, no. April, pp. 676-691, 2014.

[12]R. Manual, "PVTi Reference Manual," pp. 1428, 2009.

[13]S. Abingdon, "PVTi and ECLIPSE 300 An Introduction to PVT analysis and compositional simulation Abingdon Technology Center," Components.

[14] S. Li and P. Luo, "Experimental and simulation determination of minimum miscibility pressure for a Bakken tight oil and different injection gases," Petroleum, vol. 3, no. 1, pp. 79-86, 2017.

[15] T. Ahmed, "A Generalized Methodology for Minimum Miscibility Pressure.” 2007.

[16] T. Ahmed, "Minimum Miscibility Pressure from EOS," 2010.

[17] W. Yan, M. L. Michlesen, and E. H. Stenby, "Calculation of minimum miscibility pressure using fast slimtube simulation," Proc. - SPE Symp. Improv. Oil Recover., vol. 1, no. April, pp. 386-401,

\section{تخمين أدنى ضغط امتزاج للأزاحة بالغازات الهيدروكربونية بالاعتماد على معادلة الحالة \\ لقاء إبراهيم هادي، سميرة محم حمد الله²} 1 قسم هندسة النفط ،جامعة بغداد،بغداد، العراق، liqaadr@gmail.com 2قسم هندسة النفط ،جامعة بغداد،بغداد، العراق، sameerahmdulla@yahoo.com sameerahmdulla@yahoo.com ، الباحث المعثل : سمبرة محلـ حمد الله نشر في : 30 ايلول 2020 الخلاصة - العامل الاكثر أهمية في حساب أمكانية الازاحة بالامتزاج هو (ضغط الامتزاج). فعند الانتاج بالطرق الثانوية فأن حقن الغازات العيدروكربونية يكون له دور فعال في تحسين معامل الاستخلاص خصوصا في حالة حدوث الامتز اج بين الغاز المحقون والنفط المكني.هناللك العديد

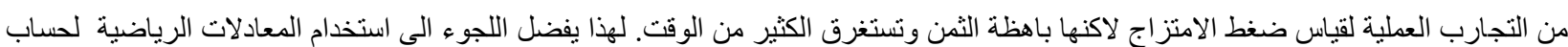
قيمة ضغط الامتز اج كونها رخيصة وسريعة. لهذا ركزت هذه الدراسة على حساب ضغط الامنز اج لبئري EB1-SADI و EB11-Tanomaa . EB ولقد

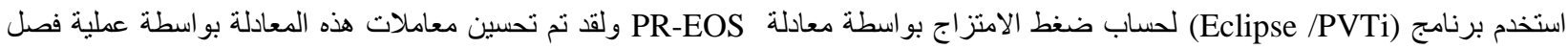
المركبات الثقبلة وعمليات التهذيب من اجل الحصول على افضل تطابق بين الخواص الفيزياوية المقاسة والمحسوبة. وأخير ا رسمت المخططات الثلاثية لتوضيح حدوث الامتز اج. الكلمات الرئيسية ـاقل ضغط الامتز اج, حقن الغاز الهيدروكربوني, الاز احة الامتز اجية. 